\title{
Rethinking Sport, Empire, and American Exceptionalism
}

\author{
Steven W. Pope \\ University of Lincoln
}

Historian Anders Stephanson has recently declared that the "United States is today the world's largest transoceanic empire. Innumerable islands under the American flag dot the Pacific and the Caribbean, the biggest and most notable being Puerto Rico. This is a colonial empire in the most conventional sense: far-flung territories and populations are held under the control of the center in a state of formal inferiority." Most Americans seem to be unaware of this empire, much less the history of how it was achieved. "Old-style imperial possessions are rarely discussed or even acknowledged," Stephanson writes, and "the overwhelming reality of imperial power in the insular possessions, then, is mirrored inversely in the insularity of the imperial power itself." 2

In recent years, though, empire and imperialism have been dragged into discourse as explanatory tropes for interpreting the recent American wars in Afghanistan and Iraq as well as for the way in which the current Bush administration responded to the $9 / 11$ attack by embracing a new imperial program called the Project for a New American Century. ${ }^{3}$ In a 2004 review essay of recent books within this tradition, Ronald Steel suggested that Americans are now "in the early stages of imperial self-recognition. Americans are only just beginning to understand the role their nation plays in the world, and the price incurred by that role. That acknowledgment is late in coming because we have been brought up on an image of ourselves as rebellious colonists winning liberation from the clutches of imperial Europe." "This growing awareness of the nation's imperial past and present comes at a time when the future of American global hegemony is now widely debated. ${ }^{5}$ As Jonathan Schell writes, what "we may in fact be witnessing is not just a contest between an American empire and its particular colonial targets but a final showdown between the imperial idea and what I like to call an unconquerable world, meaning a world that has the will and the means to reject any imperial yoke."6 Such issues have evoked a lively debate among imperial historians, political economists, and cultural commentators.

Whereas empire has been a central topic for British sport historians during the past couple of decades, the topic has been virtually out of bounds for their American counterparts. ${ }^{7}$ With a couple of noteworthy exceptions, American sport historians have hardly analyzed their subject within a global context-much less have they demonstrated, unlike their colleagues in sport sociology, that sport has

Pope is with the Department of Humanities, University of Lincoln, Lincoln, United Kingdom. 
had a role in the development of the modern empire and imperial mentalities. Although Steven Riess noted in 1997 that sport and foreign relations have not been adequately integrated into the American literature, ${ }^{8}$ prior to the publication of a couple of recent works (most notably by Gerald Gems), ${ }^{9}$ only Allen Guttmann had explored the implications of cultural imperialism as manifested in the diffusion of American sport in his 1994 book, Games and Empires. ${ }^{10}$

This neglect derives from at least three cultural and scholarly factors. First, there has been a general, American reticence to acknowledge the existence of an empire or a well-established imperial mind-set in their nation's past (and present). Outside of left-wing polemics and revisionist histories, the notion of an American empire as one comparable to previous empires has rarely been acknowledged in either popular or academic discourses. Americans have imagined themselves to be fundamentally unique, special, or "exceptional." This historical amnesia of the nation's past stems from the hold of popular historical narratives of American "westward expansion" and "manifest destiny," which have portrayed a benign, often romantic story of "aggrieved innocence." "As late as the 1970s, leading historians of American diplomacy, like Ernest May, suggested that America's rise to a global power was merely fortuitous- " greatness was thrust upon it" by larger, historical forces. ${ }^{12}$ Second, following on this cultural explanation is the fact that historians (including sport historians) have been seduced by the interpretive talisman that is American exceptionalism - a term, as Trevor B. McCrisken, explains, is used to describe "the belief that the United States is an extraordinary nation with a special role to play in human history; a nation that is not only unique but also superior." First used in the early nineteenth century by Alexis de Tocqueville (although the idea can be traced back to colonial times), it became a central component of American national identity and a powerful ideological influence on U.S. foreign policy. ${ }^{13}$ This exceptionalist ideology persisted throughout the twentieth century-articulated by such luminaries as Frederick Jackson Turner and promulgated prominently in the "consensus" historiography in the 1950s. This strain outlived the new social history, with its emphasis on the themes of race, class, gender, and ethnicity that appear to cut across the central tenets of the faith in the United States as an exception. ${ }^{14}$ And, third, American sport historians have curiously remained on the sidelines of the conceptual and theoretical debates that have been advanced within the parent discipline.

American sports history flourishes and yet, simultaneously, the field is increasingly estranged from the mainstreams within social, cultural, and political history. ${ }^{15}$ After its rise to become a promising subfield of social history during the 1970s and 1980s, American sport history came to be recognized, albeit grudgingly in some staid circles, as a serious area of inquiry during the 1990s. But after achieving its status as a recognized area of research, it has become seemingly less visible and relevant within mainstream history. Seldom are the revered sport history monographs cited in the footnotes and bibliographies of key works in American history, and even more seldom do sport historians publish their research in the leading American history and American Studies journals. ${ }^{16}$ Even though there is a new generation of scholars who are transforming the field of sport history in the United States, many sport historians have been less reflexive about the wider implications of their research ${ }^{17}$ at precisely the moment when their peers in social, cultural, and political history have become more actively engaged in debates about method and 
epistemology. ${ }^{18}$ This is not seen as problematic by many practitioners. Stephen Hardy has argued that sports history no longer needs to actively court the debates within social and cultural history. "If academic sports history is to thrive and have a future, it must have," according to Hardy, "a space of its own . . sports history begins with questions arising within that domain of life we call sport."19

What follows is an argument against this view of sport historiography. The analysis of sport within the development of the American imperial idea provides a suggestive case study for the way in which sport historians fruitfully integrate their rich empirically based work within some of the recent debates raging within the American historical profession. Such a pursuit highlights the various ways in which the study of sport is relevant to contemporary political discourses about the American imperial tradition and how sport as a key carrier of Americanism is an important, although sorely neglected, dimension within cultural history and diplomatic history, as well as the history of international relations. ${ }^{20}$

One of the critical debates within American history during the past decade has focused on the viability of American exceptionalism as an interpretive paradigm. There has been a thorough de-provincializing of the notion of American exceptionalism - arguably the most resilient interpretive framework within the profession during (and since) the Cold War. ${ }^{21}$ In his presidential address to the Organization of American Historians in 1993, John Higham affirmed that from the mid-nineteenth century until the 1960s, "the nation was the grand subject of American history." The leading American historians "either devoted themselves to explaining the nation's distinctiveness, as a polity and a people, or took it for granted"; nevertheless, the "reality and importance of that distinctiveness were never in question." Although historians have debated the causes of the nation's alleged uniqueness and have divided into rival camps, they have generally embraced the notion of exceptionalism. In spite of the proliferation of numerous subfields associated with the "new" social and cultural history-notably women's history, immigration history, African American history, Native American history, and working class history-historians continue to situate their work, according to Higham, "largely within the American arena and (except for early American history) make contact only intermittently with similar projects in other countries." 22

The discussion about how American historians might move beyond an exclusively nation-centered, American-exceptionalist perspective has advanced in recent years toward a consideration of transnationality and the need of better situating American history within world history. ${ }^{23}$ Thomas Bender, one of the leading figures in this revisionist vanguard, argues that historians must integrate the stories of the American past with other, "larger stories from which, [and] with a kind of continental self-sufficiency, the United States has isolated itself. . . . We must understand every dimension of American life as entangled in other histories [and that] other histories are implicated in American history, and the United States is implicated in . . . similar projects in other countries." ${ }^{24}$ Bender and Ian Tyrrell maintain that the conventional framing of American history no longer fits or connects us "to the transnational and global developments which have invited, even demanded, a reconsideration of the American past from a perspective less tightly bound to perceptions of the nation as the container of American history." ${ }^{25}$ Both argue that the legacy of exceptionalism can only be properly laid to rest by overcoming a strictly national focus and embracing a transnational mode of analysis so as to 
interpret the American story not as an exception, as Tyrrell writes, to "patterns of national power in a world of nations but as a particular, and constantly changing expression of complex forces." 26

This line of enquiry exposes the problems inherent in an American exceptionalist interpretive tradition. Historians have ably documented how the nation's history consistently departed from this comforting ideology. Not only did the new American nation accommodate empires, but it also, as historian Mary Heiss writes, "often worked to perpetuate colonial institutions and arrangements in the pursuit of what were perceived to be more pressing international goals." In sum, she maintains that "the historical record suggests that the noble ideals and lofty principles on which the nation was founded were not the sole determinants of its policy on empire... [but rather] an often conflicted and inconsistent position on things imperial." 27

What follows is merely a preliminary effort of suggesting how well-established themes within sport history, if considered within the context of the longer history of the American imperial idea, can broaden our understanding of American sport within world history and, as a result, enable sport historians to make more effective cross-cultural analyses. ${ }^{28}$ Within this discussion, I will emphasize how various historical anecdotes (and historiographical generalizations) substantiate an imperial mind-set throughout the American sporting past. In so doing, however, I wish to allay criticisms of constructing a "straw man" (i.e., an interpretive framework that emphasizes "empire" and "imperialism" as determinative rather than suggestive). ${ }^{29}$ I recognize that there are instances that simultaneously evoke both imperialism and exceptionalism; however, such cases are outside the ambit of this particular essay. ${ }^{30}$ Instances of multi-interpretive emphasis are inevitable in the process of historical inquiry. Simplifying "gray" interpretive problems is endemic to historical analysis. All historians slip (consciously or unconsciously) into caricaturing or dismissing oppositional positions - it is simply a fundamental characteristic of historical argumentation. ${ }^{31}$ In addressing the "fallacies of semantical distortion" in historical argumentation, David Hackett Fisher notes the importance of formal definitions. ${ }^{32}$ But merely "defining one's terms" is not as simple as is often imagined. Precise definitions are usually constructed for a particular purpose and are advanced only by drawing an arbitrary line. As Fisher explains, this is often dangerous in practice because "such a distinction is arbitrary, and merely a matter of degree, that no 'real' distinction exists"; conversely, "it is possible to err in the opposite way and be deluded by language into a reification of the arbitrary line." 33

This caveat underlines the arbitrary nature of facts, language, historical narratives, and conceptual frameworks. My thinking of these thorny issues has evolved in recent years as I have gravitated toward a postmodern position to historical enquiry. ${ }^{34}$ Deconstructionists maintain that "truth" is always relative to the differing and predisposing frameworks for interpreting a subject and that language does not correspond directly to a given "reality," and they deny that final or "true" definitions are possible. According to postmodernists, if direct access to the past is impossible, then, as Christopher Butler notes, "all we can have are competing stories, which are variously given coherence by their historian narrators, and the past is no more than what historians say that it is." In this way, historiography always stands in for history in most instances. Postmodernist relativism, however, is not synonymous with an anything-goes view of history. Rather, as Butler maintains, this critique of traditional historical assumptions suggests that "we should be more skeptically 
aware, more relativist about, more attentive to, the theoretical assumptions which support the narratives produced by all historians, whether they see themselves as empiricists or de-constructors or as postmodern "new historicists." 35 I hope that this article raises these issues (either explicitly or implicitly) for future debate among sport historians. ${ }^{36}$ Again, the essence of this particular piece is an argument in favor of more critical, transnational analyses of American sport history that more explicitly engage recent historiographical debates within the mainstream historical profession-most particularly, the issues surrounding American imperialism and American exceptionalism (both of which themes have received short shrift to date by sport historians).

\section{Sport and the Development of an American Imperial Mentality from the Colonial Era Through the Nineteenth Century}

In his rhapsody to the imperial tradition, Niall Ferguson maintains that "the United States is an empire but that it has always been an empire." ${ }^{37}$ The established characteristics of an early American imperial identity are well known. Born through revolution against British imperial rule, the new American nation perceived itself as anti-imperialistic — as a benign, benevolent liberator of the colonized, an ideology promoted through a rhetorical assault against the "evils" of Old World empires. The earliest statement of an emergent imperial mentality was articulated by John Winthrop, governor of the Massachusetts Bay Colony, who in a 1630 sermon maintained that the Puritan colonists, a chosen people, had established a new kind of community - "a city upon a hill." That self-identification of uniqueness and superiority underpinned the expansionist policies of the young nation as it expropriated native lands in North America and abroad well into the twentieth century.

Between the revolutionary era and the mid-nineteenth century, there were numerous pronouncements against European presence in North America but the nation often lacked the military and diplomatic muscle to eliminate foreign threats to American territory. Nevertheless, the 1803 Louisiana Purchase of a massive territory from France (for $\$ 15$ million) — which doubled the area of the United States, and the Monroe Doctrine, enunciated in 1823, proclaiming that the United States would view with displeasure any European intervention in the Americas - provided clear evidence of an imperial mentality. Historian William Appleman Williams identified that the Monroe Doctrine, which underpinned American foreign policy throughout the nineteenth and twentieth centuries, was "clearly the manifesto for the American empire." 38 The U.S. government put muscle behind such pronouncements and manifestos first in a war with Mexico (1846-48) through which Mexico ceded two-fifths of its territory for the modest sum of $\$ 15$ million. The overwhelming thrust of federal and private activity during the nineteenth century was focused on westward expansion driven by a divine faith in "manifest destiny," which underpinned a burgeoning national (although rarely seen of as imperial) identity. ${ }^{39}$

The development of an American sporting tradition was, thus, incubated within a wider struggle against European colonialism as well as within a messianic sense 
of national destiny to conquer and transform the continent. The clearest early manifestation of the new nation's imperial mentality was in the confrontation between British colonials and native Indians, who had occupied the continent before English colonization. From the seventeenth century onward, as Elliott Gorn notes, English colonists and native Indians did not borrow freely from each other given the fact that "disparate cultural contexts gave [the games] different meanings." 40 Beyond cultural differences, the long history of random racialized violence between European whites and native Indians became more systematized during the nineteenth century with the creation of the Bureau of Indian Affairs (1823) as the U.S. government embarked upon a program to remove and resettle Indians onto reservations, a program that reached its apogee between the late 1860s and the 1880s during a series of battles waged by the War Department.

There is no clearer evidence of an imperial mentality in nineteenth-century American history than in the manner by which Indians were forced into a type of internal colonialism. Within the realm of sport, several historians have documented how this process materialized at the Carlisle Indian Industrial School during the late nineteenth and early twentieth centuries. ${ }^{41}$ Spearheaded by the federal government and executed with the help of educators, the boarding school was designed to assimilate Indians into white-American society by obliterating tribal identities and cultural heritage outside the reservations. Educators believed that sports and recreation could improve the physical and intellectual capabilities necessary to counteract the supposed "influences of unfortunate heredity" as well as reinforce the notion that Indians could be assimilated within mainstream, white American society. On the other hand, the "American" sports of baseball and football were imbued with different meanings by Indian student athletes, who both affirmed and resisted such assimilationist aims. As Ray Gamache has recently suggested, sport at the boarding schools enabled Indians to gain not only an education but also a chance to beat whites at their own games in a "milieu in which to construct a collective identity and sense of pride in self, cultural traditions and memories. Sports, then, served as a meeting place, a mythic landscape where whites and Indians found both transformation and persistence-mutually exclusive interpretations and shared interpretations." 42 Athletic programs at Indian boarding schools, thus, represented a prop to American imperial thinking at home while simultaneously offering a venue for resistance to empire for native colonials.

Slavery constituted the other key realm within which American imperial thinking developed most powerfully between colonial times and the Civil War (fought between 1861 and 1865). It is impossible to understand the construction of national identity without due consideration of the ways in which American notions of "freedom" were inextricably linked to slavery. ${ }^{43}$ Although African American history has been one of the most fruitful subfields within the historical profession since the 1970s, relatively little work on black sport and leisure before the late nineteenth century has been published. ${ }^{44}$ Although slaves raced thoroughbreds and boxed in "battle royals" arranged by their masters, most of the scholarship on southern blacks has focused on the ways in which slaves created a separate leisure culture within the context of unfree labor and racialized segregation-all of which clarifies our understanding of internal forms of colonialism (although most scholars have 
not deliberately situated their work within the imperial context). Hunt Boulware's recent research into slave leisure in the Low Country of Georgia and South Carolina challenges some of the well-established generalizations about the strict racial segregation of southern culture and thereby sheds new light upon the struggle over sporting pastimes within the colonial context. Boulware demonstrates how slavery was imbued with historical contingency and human agency-a history in which slavery was made and remade by men and women on their own terms, if rarely to their own liking. In his analysis of "the biracial dynamics" within tracks and taverns in colonial Georgia and the Low Country, he argues that black slaves participated as jockeys, trainers, spectators, and gamblers and, in so doing, became key players in the South's most prominent sporting venue, horse racing. He maintains that slaves actively integrated themselves into many leisure spaces through a process of collaboration (or negotiation) with the low country's elites as well as a middling layer of shopkeepers and entrepreneurs. ${ }^{45}$

When compared with colonialism in other parts of the world, then, the dynamics of sport within America's internal colonial arrangements do not seem so "exceptional" after all. Although power was skewed in favor of the colonizers, the colonized peoples negotiate the prevailing parameters - albeit within delineated spaces.

Sport's place within an early imperial imagination was connected to racism, and it was abetted by a Protestant religious ideology. Gerald Gems has shown how, as early as in the 1820s, American missionaries arrived in Hawaii and preached the virtues of Protestantism and capitalism as part of a fledgling effort to introduce the WASP values of time and work discipline, initially through residential boarding schools but later through sport. By the 1840s, the missionaries, according to Gems, "enjoyed great influence as advisors to the monarchy, instituting judicial, commercial and capitalist systems unfamiliar to the native population." ${ }^{6}$ Such ad hoc efforts on behalf of missionaries evolved into a more systematic effort of "sweetening the gospel with sport" (to use William Baker's felicitous phrase) by the YMCA beginning in the 1850s and 1860s. Baker has demonstrated how the American YMCA movement "created a principled but flexible institution run by highly motivated, well-trained personnel, an institution equipped to carry the gospel of sport all over the world." The YMCA was the most visible and effective organization to promote a white, middle-class, Anglo-Saxon, Protestant ideology of "muscular Christianity" within Britain, in the United States, and throughout the world. Although the American YMCA embraced sport sooner and more zealously than their British counterparts, muscular Christians in the United States, according to Baker, "faithfully reproduced a highly class-conscious attitude that was born and bred in Britain." ${ }^{47}$ In short, the trans-Atlantic ideology of muscular Christianity provided a crucial moral justification for the institutionalization in the United States and Britain as well as a sense of mission for the export of American and British sporting practices abroad. Imbued with notions of manifest destiny, social Darwinism, and cultural superiority, the YMCA-styled muscular Christianity informed American imperial ideas with regard to sport.

The muscular Christian view of American sport was bolstered by a commercial imperative that Kenneth Cohen dates to the revolutionary period. Although sport historians have traditionally posited rival, vernacular sporting cultures within colonial America (a noncommercial, recreational tradition in New England and a class-segregated cash- and status-oriented one in the Chesapeake)—which were 
underdeveloped until urban, industrial, and capitalist development during the antebellum period-Cohen documents how sporting leisure had already developed into a heavily capitalized and thoroughly commercial form by 1840 , a form that would inhere until the late nineteenth century (contrary to modernization arguments locating this transition from between 1820 and 1860 or even later in the nineteenth century). According to him, the entrepreneurial risk, rise of the profit motive, and competition within an emergent leisure industry dates to the period of aggressive speculation immediately following the revolutionary war of independence. ${ }^{48}$

Whereas sport historians have noted the secular ideological opposition to sporting leisure that arose in conjunction with the resistance to the British empire during the 1770s, Cohen shows how the demonstrations in support of American independence simultaneously carried the hallmarks of such formally banned pursuits (i.e., sponsorship by wealthy leaders; participation from the lower sort; and contest over authority, status, and control of the event)—in effect demonstrating the ways in which the social practices of colonial sport informed the political mobilization central to realizing revolution. ${ }^{49}$ The profits accrued by urban merchants who provisioned the West Indies and the troops during the French-Indian War enabled them to erect the first purpose-built sporting venues in coastal cities (e.g., racetracks, theatres, and taverns), and, after the revolution, many of the same merchants and landowners sought to extend their influence over fellow citizens by providing and controlling sporting leisure. ${ }^{50}$

The final component linking sport and the imperial idea to be noted here is the elaborate, sustained effort of defining and dramatizing a distinctively American national identity during the late nineteenth century. Through public ceremonies, festivals, and commemorations, and within the performative dimensions of newly created team sports and sporting traditions, Americans delineated their cultural practices as distinct from those of Europe and the rest of the world. The process by which "invented" rituals, mythologies, and discourses imbued sport as a key cultural carrier of patriotic meaning during the heyday of popular nationalism has been extensively documented. ${ }^{51}$

Before the nation's extension of empire outside North America, there were few more-incisive examples of this emergent American imperial mentality toward sport than that of the Albert Spalding-led world tour of professional baseball players in 1888. Spalding sought to market baseball—reputedly a distinctly American national pastime - as a global game, as well as to extend his sporting goods empire abroad. Nevertheless, Spalding's efforts at promoting the global diffusion of baseball have never been explicitly contextualized within American imperial thinking. In his new book, Thomas Zeiler demonstrates how the 1888 baseball tour revealed the roots of American empire. Characterizing the baseball adventurers as diplomats of budding imperial notions, Zeiler shows how the baseball tourists carried dominant nationalistic values as well as a more general cultural ordering of races and societies; they combined "an entrepreneurial spirit with principles as well as imperial intentions" and were part of a larger project of "reshaping the world in the coming century under American leadership." ${ }^{2}$ Beyond the patriotic and chauvinistic rhetoric of the baseball men, however, ran "business calculations that served the nation's power structure, on which later imperial-minded leaders based the nation's strength." Late nineteenth-century industrial and financial capitalism "disciplined the world economy and provided a springboard for empire." By linking baseball to a growing 
U.S. presence overseas and "viewing the world as a market ripe for the infusion of American ideas, products, and energy," Spalding's world tour "packaged business, technology, culture, and a political representation into a weighty national identity that promised a future of imperial eminence." ${ }^{53}$

In short, even this cursory review of some of the key issues pertaining to early American sport history demonstrates the viability of recasting the interpretive contours into a paradigm anchored in a consideration of the ways in which sport promulgated an early American imperial mentality. Such an approach could be used to synthesize the various, well-established lines of inquiry-race, religion, commercialization, urbanization, nationalism - into a modified interpretation of American sport that encourages transnational comparison and is less beholden to the notion of American exceptionalism.

\section{Sport and the New American Empire, 1898 to 1945}

Between the Spanish-American War and WWII, the United States achieved not only a sprawling empire with colonial possessions and protectorates in the Far East and in the Caribbean, but it also emerged after 1945 as a bona fide superpower. Although one can find numerous protestations within American discourse about the "evils" of European empire, by the late nineteenth century it became clear to the American ruling interests that the United States could not be left behind in securing markets for expanded foreign trade as well as in procuring key resources for industrial production. The long-revered anti-imperialist national mythology hailed as evidence of the nation's "exceptional" place in the world was eclipsed by an openly imperial rhetoric and an "open door" foreign policy bolstered by a global police presence-in short, a growing recognition that the nation was increasingly embracing the ideology and practices it had long denounced. As Heiss writes, during the early twentieth century the United States "successfully warded off foreign threats in the Western Hemisphere that could imperil its interests, neutralized the spheres of influence system in China to its own benefit, and shaped the initial phases of colonial devolution in ways that suited its ideas of racial hierarchy and Western (especially American) superiority ... [and in so doing] the nation revealed its selfconception as a world power with worldwide interests - and ultimately worldwide influence. ${ }^{54}$ A notable acknowledgement of this evolving imperial viewpoint was the Roosevelt Corollary to the Monroe Doctrine enunciated in 1904 by President Theodore Roosevelt, who claimed for the United States "international police power" within the Western hemisphere. This policy was embraced and operationalized by Roosevelt's presidential successors, William Taft and Woodrow Wilson. By World War I, Cuba, Panama, the Dominican Republic, Haiti, and Nicaragua were in some kind of protectorate situation, while Puerto Rico remained an outright colony, and most of these countries experienced actual military intervention during the 1910s and 1920s. Bender explains how the United States entered the twentieth century "well experienced in taking territory and in the affairs of empire." In seeking and protecting markets for American agriculture, capital, and manufacturing, it "competed aggressively with the European powers for market share in the global economy. The United States was, thus, part of a larger history of the European or Western economic and cultural domination of the planet ... that began in the fifteenth century." Although territorial acquisition and military intervention would be 
less extensive than what characterized the British empire, a new-styled American neoimperialism that capitalized on the establishment of financial hegemony as a newer, "softer" vehicle of empire. ${ }^{55}$

Early twentieth-century American imperial visions abroad were anchored in a domestic ideology that drew upon ideals of both civic and racial nationalism. In his insightful synthesis of modern American history, Gary Gerstle argues that these two strains of American nationalism imparted "a clear, if paradoxical, shape" to what he terms the "Rooseveltian nation"; the two powerful and often contradictory ideals shaped the American nation throughout the twentieth century. The civic nationalist creed implied "political and social equality for all, irrespective of race, ethnicity, or nationality, and a regulated economy that would place economic opportunity and security within the reach of everyone" was simultaneously espoused alongside a racial nationalism that conceived of America "in ethnoracial terms, as a people held together by common blood and skin color and by an inherited fitness for self-government"-from which perspective "Africans, Asians, non-white Latin Americans, and, in the 1920s, southern and eastern Europeans did not belong ... and could never be accepted as full-fledged members." ${ }^{56}$ The individuals who celebrated and championed the diffusion of American sport abroad during the first half of the twentieth century reflected the tensions between these two dominant visions of the national identity as they fused together notions of race, religion, capitalism, and imperialism into a formidable imperial ideology. ${ }^{57}$

With a well-established national sporting culture (based upon modified forms of the imported British sports $)^{58}$ by the turn of the century, Americans sought to evangelize and export their games and values abroad as part of a general imperialist effort. The effort was commenced haphazardly by a presumed position of superiority to the people whose land they coveted or whose trade and natural resources they sought. Americans, as Bender writes, "presumed that their own parochial assumptions were universal and should be controlling in intercultural and international exchanges." ${ }^{59}$ Gerald Gems shows how American imperialists found many rational uses for sport in "the cultural interplay that transpired in colonialism." As he writes, "sport forms and practices offered myriad responses in the negotiation of culture, ranging from acculturation to political and surrogate warfare. The only assurances that were dictated confirmed that both dominant and subordinate groups would be changed in the process." ${ }^{60}$ American imperialists created "comprehensive athletic programs in schools, parks, playgrounds, and settlement houses, often run in close alliance with the YMCA, and attempted to inculcate an ideology of whiteness with varying degrees of success." 61 The colonials readily warmed to American sporting practices (but not especially to the cultural-ideological packaging) and proved themselves to be quick studies (especially of baseball and basketball) and regularly beat the Yankee imperialists at their own game (often with new styles of play, different from those of their instructors).

American baseball arrived abroad (in Cuba and Japan) as a function of Britishstyled, Victorian-era imperialism by trumpeting national ideals and ideas of culture and solidifying white preeminence in the global racial order. ${ }^{62}$ In short, as Francis Cogliano concludes, the history of baseball in the Americas suggests "that in their quest to define themselves Americans should not stress the ways in which they are different from Europeans. Rather they should . . . consider the common history, including cultural exchange as well as military conflict and economic domination 
which binds them to their neighbours." Again, race and racism permeated this process as it did in earlier epochs of American history. In spite of America's entrenched racism rooted in slavery, Americans learned and applied a wider, racialized view of the world from the long-established British practices of denigrating colonial groups' practices within popular discourse/culture. Within the realm of sport history, British historians have documented this tendency, yet such analysis has seemingly eluded most American sport historians. ${ }^{63}$ The expansive literature on sport and race $^{64}$ can be reconceptualized globally and transnationally to explain how "race, an AngloSaxon construct that imbedded social class, religious, and gender connotations, and accorded certain rights and privileges" 65 was connected to notions of American empire (and not just an obstacle to political and social equality in America). This important point underlines precisely Bender's call for a transnational approach to American history. ${ }^{66}$

The end of WWI represented an important watershed in American imperial thinking with regard to sport. Not only did religious faith link up with sporting fervor in the patriotic effort, but also, as William Baker maintains, "ever afterward, and especially on the international Olympic stage when American athletes confronted representatives of fascist and communist states, the American credo would be decidedly Trinitarian: faith in the Nation, faith in God, and faith in Sports." ${ }^{67}$ Americans emerged from WWI with a newfound sense of confidence in their ability to exert cultural and political muscle with other European powers as well as within the nation's established spheres of influence in the Caribbean and the Far East. This invigorated cultural swagger derived from the fact that after WWI the United States had eclipsed Britain and had become the new center of economic power.

Nowhere was this sense of global mission any more evident than in the attempt to convert Europeans to American sport. United States military personnel saw themselves as international missionaries. "Thanks to the American doughboy, and his confreres, the marine and the blue jacket, sport, the world over, is about to have its greatest revival," asserted one prominent sportswriter. Noting that baseball had always "followed the flag" to Latin America and the Far East, he surmised that it had taken "the big war" to introduce the game throughout Europe, and as such the growing popularity of American sport signaled "a new era for sport"- - one that reflected the "increased interest and general feeling of good will toward the people of this country." Fletcher Brockman, a YMCA spokesman, made the case in even more explicit terms: "To teach half a billion people the true meaning of democracy and train them in its wise use," he proclaimed, was "the supreme and urgent task before the world today." At no point were the American athletic missionaries' efforts more successful (in the immediate short term anyway) than during the 1919 Inter-Allied Games. ${ }^{68}$

The elaborate postwar military Olympiad was organized by the YMCA $^{69}$ with the cooperation of the U.S. Army. The military commanders of twenty-nine nations, colonies, and dependencies were invited to participate in the event held in the newly built (by the YMCA) Pershing Stadium in the Bois de Vincennes near Paris. During the two weeks of competitions, nearly 1,500 athletes representing eighteen Allied nations or dominions participated in the largest athletic program hitherto executed under one management. The Games Committee interpreted the contests in unmistakably ideological terms - namely, to show how "wholeheartedly the nations that had striven shoulder to shoulder on the battlefield could turn to 
friendly rivalry in the stadium" and thereby spread the cause of sport to countries that "came into being in the travail of world war and which in the future will take part in the improvement of athletics."70

This episode is illustrative of how Americans broadened their sense of imperial destiny. Assuming that just as the nation had supplanted Britain as the emergent global power, they also, as Mark Dyreson writes, "assume[d] that their sporting traditions would make the globe more American-precisely as the British had believed about British sports and a British world culture a generation earlier." Dyreson has skillfully documented how athletic promoters, business leaders, and government officials have used the Olympic Games to promote American culture and sport as something to be emulated by the rest of the world. ${ }^{71}$ Nevertheless, Dyreson astutely notes the irony of American efforts to spread its national culture through sport prior to WWII_- "just as the United States had borrowed from Great Britain the idea of using sport as a tool to construct national identity whilst at the same time rejecting the British notion that the tool would inevitably spread Britishstyle culture around the world, so too did other nations accept the American notion of defining nationhood through sporting prowess but rejected Americanization in favor of their own nationalisms." 72 The impact of this process upon local and regional sporting cultures during the first half of the twentieth century remains to be more fully explored by sport historians.

Another critical topic that has been neglected by sport historians is American efforts in the consolidation of the international sports world. The literature is strongest with regard to American involvement in the Olympic movement, but, as Barbara Keys documents in her excellent, new book, Americans sought to "mold international sport into forms consonant with the values and ideals of U.S.-style capitalism and democracy" (as well as imperialism). ${ }^{73}$ As Keys writes, Americans were "convinced that the popularization of sport was an effective means of spreading their own values and ideas, and they framed their participation in international sport as a moral crusade to spread peace and democracy." This process was not led by the state, but rather, by private groups that exploited sport to promote good relations with countries in Europe, Asia, and South America and to spread national values. ${ }^{74}$ Although Americans had only limited success in exporting their dominant team sports abroad, they exerted a profound influence on international sport during the 1920 s and 1930s by "imbuing it with moral and technocratic impulses, and in expanding its connections to the worlds of entertainment and mass culture." At home, according to Keys, "U.S. sports victories helped affirm beliefs in the country's benevolent role in the world and in the superiority of democracy as a political and social system"75 _ notions central to American imperial identity within the realm of sport.

\section{Sport and Pax Americana Since WWII}

A final stage in the development of an American imperial idea commenced with WWII. ${ }^{76}$ The most oft-cited statement of the emergent, dominant view of American imperial ambition is that of Henry Luce, publisher of Life magazine, who declared in 1941 the coming of the "first great American Century." Luce was a critic of British and European imperialism and maintained that his view was internationalist but not imperialistic (i.e., that Americans merely sought to shape the postwar world 
with democratic ideals and institutions). ${ }^{77}$ Nevertheless, Luce's statement bespoke of America's allegedly "exceptional" place in world history: "the time has come to accept wholeheartedly our duty and our opportunity as the most powerful and vital nation of the world and in consequence to assert upon the world the full impact of our influence, for such means as we see fit." " 8 Such a view exuded an ethnocentric worldview, which, as Donald White notes, "did not fully take account of the life and culture of other peoples." 79

The nation's opposition to imperialism and empire notwithstanding, the desire to see "subjected" people granted independence and self-government (as articulated in the Truman Doctrine) became the ideological basis for the development of an anticommunist empire. As Heiss writes, "on one level [it] served to fulfill the nation's mission to remake the world in its own image, [and] it also served the nation's Cold War foreign policy." ${ }^{80}$ Although the nation was committed to colonial aspirations for independence, the ruling elites were convinced that the Soviet Union had embarked upon global expansionism, and, as a result, American policy makers pursued anticolonial (and counter-revolutionary) responses in the interest of "containing" communism. In short, elites chose Cold War strategies over anticolonialism, and in so doing the self-professed, anti-imperialist nation ultimately proved not to be so anti-imperial after all.

During the early stages of the Cold War, imperialist rhetoric that underpinned the international expansion of American sport became, interestingly, less strident. Diplomatic historian Marilyn Young believes that we must differentiate the language of imperialism and the language of empire and maintains that the two are "in constant tension, even contradiction." ${ }^{81}$ Whereas there were abundant examples of the importance of spreading American sport (and the corresponding national values) abroad, the United States became less explicitly imperialistic in tone, and perhaps more nationalistic in its approach to sport. The American military and federal government benefited from the wartime service of more than five hundred major league baseball players (including thirty-two Hall of Famers) in sustaining wartime patriotic morale. American sport also became the grist for extolling the "American Way" by commentators and sportswriters, such as John Tunis, who asserted that sports in the United States reflected the nation's positive values-hard work, democracy, and the opportunity for individual achievement. ${ }^{82}$ As such, as Jay notes, sometimes the American Way was "shorthand for the philosophical values of equality, democracy, and tolerance, all of which had far-reaching consequences for social justice and social change." Yet notions of "fair play" and the "level playing field" remained elusive for African Americans, in particular, such that the "American Way" meant winning as proof of the nation's global prowess. ${ }^{83}$

The thrust of American sporting passion and discourse resonated most powerfully within Olympic competitions, which allegedly demonstrated the national and ideological superiority of both Americanism and capitalism. The modern Olympics began in 1896 within the context of raging imperial rivalries and, as such, provided an ideal venue for imperialist powers to symbolically dramatize their power (both real and imagined). During the Cold War, the Games fixed ideas of the enemy (and the "other") in the popular imaginations of the East and West. As Jay writes, "ironically, it was this animating desire to crush opposing ideological views that made watching the Olympics so fascinating. International brotherhood and harmony are fine ideals, but they do not make for scintillating sports rivalries." ${ }^{\prime 4}$ 
Sport bolstered American visions of the nation's sense of mission and celebrated the "American Way of Life" during the Cold War. Jay suggests that "no matter how much fun playing sports was, the need to remind youngsters of their Cold War responsibilities was never far from the surface." ${ }^{85}$ Such Cold War imperial discourses must receive brief discussion in the restricted space of this article. Although a heretofore neglected area of scholarly inquiry, sport diplomacy and policy during the Cold War provides especially fertile terrain for reassessing the notion of American exceptionalism and for better understanding how East-West tensions animated the nation's imperial mentality toward sport. ${ }^{86}$

Globalization has fundamentally altered the terms and conditions for understanding empire and imperial modes of thinking. Whereas before WWII the locus of scrutiny focused on the actions and official policies of the nation state (and national institutions), in recent decades, the imperialist torch has been carried by multinational and transnational corporations. As Michael Silk et al. explain, the locus of control "in influencing the manner in which the nation and national identity are represented becomes exteriorized through, and internalized within, the promotional strategies of transnational corporations." Simply put, the politicocultural nation state of the nineteenth and early twentieth centuries has been "replaced by the corporate-cultural nation"- - a process that Silk and Andrews term corporate nationalisms (the way in which national cultures are "corporatized, and reduced to a branded expression of global capitalism's commandeering of collective identity and memory")_- processes that are qualitatively distinct from those that helped to constitute the symbolic boundaries of maturing nation-states during the nineteenth century." ${ }^{87}$ Whereas even a decade ago the debate about the globalization of sport focused on how this process boded to marginalize, if not transcend the efforts of nation states, in recent years a number of scholars have questioned such suppositions. One of the few American sport historians who has weighed into this debate (and one of the few who has attempted to integrate American sport within world sport history) is Mark Dyreson, who has argued that the twentieth-century history of globalized sport has "served to invigorate national cultures rather than to transform them into cosmopolitan partners in a new world system . . . [and in this sense, as] the language of sport has spread around the globe, it has functioned as an element in national discourses." 88

To date, the analysis of the extent and effects of globalization has been conducted almost exclusively by sport sociologists rather than sport historians. Alan Bairner maintains that it is a moot point whether globalization "represents evidence of Americanization as opposed simply to the worldwide triumph of capital" and suggests that "an analysis of the actual experience of other societies" is required "to ascertain the extent to which [such] developments are indicative of the successful Americanization of sport." ${ }^{\text {" } 99}$ Thus, even as invaluable as is the work of LaFeber and other historians who have documented the ways in which American sport has affected the style and organization of sport abroad (characterized as cultural imperialism), there has been relatively little empirical analysis of the results of this penetration of national borders and indigenous sporting cultures. ${ }^{90}$ Fortunately, there are some useful sociological studies that provide suggestive lines of enquiry for historians.

In their study of the marketing of the National Basketball Association (NBA) within English subcultures, Mark Falcous and Joe Maguire demonstrate the 
difficulty of gauging the impact of American basketball on the development and consumption of "indigenous" basketball in the East Midlands during the 1990s. Within the context of "globalization," the NBA adopted a forward-looking policy to expand the league's presence outside North America during the 1990s through the production of television shows, magazines, licensed merchandise, and the promotion of migrant players to the NBA. Such efforts were only partially successful at extending the visibility of the American game in Britain. Even though, in imperial fashion, the NBA pointed to the substantial global television coverage of its product (games broadcast in 199 countries on 104 telecasts in 40 languages reaching 600 million households in the year 2000), the American professional version of the game was not widely consumed by British audiences. ${ }^{91}$ According to Falcous and Maguire, this case study underlines the need to "explore the dynamics of local cultural impacts and responses to the activities of organizations such as the NBA and the complex synergies that inform the pervasive global presence they constitute." Such analyses serve to remind sport historians of the importance of conducting "comparative work from a diverse range of localities [so as to] establish further evidence of the identity politics and established/outsider relations" inherent in imperial/colonial sporting exchanges. ${ }^{92}$

Although only occasionally documented by sport historians, the leading edge of post-WWII American sporting imperialism has been characterized by the use of "soft power" (or cultural imperialism)—subsuming sport within the broader exportation of popular culture, entertainment, fashion, music, fast food, and the like-which seemed to be less overtly threatening than the more systematic diffusion of earlier times. During this phase, American corporations have fundamentally shaped global sport, especially the manner in which it is organized, packaged, and marketed. Robert Lewis has recently maintained that Major League Baseball played a type of economic "hard ball" as an "imperialist neo-colonizer"-a history rife with class and racial implications. According to Lewis, MLB's imperial pursuit of talent from the Caribbean region became systematic after the failure of its internal colonial practices within the United States, which began first with the recruitment of white rural players during the 1920s and 1930s, and then black players, for the Negro League, in the late 1940s. "As a result of resistance from its colonies at home and abroad as well as greater market competition," he contends, "MLB now plays a more cultural "soft ball' as a multinational corporation." ${ }^{93}$ However "soft" MLB's presence actually is within Latin America, currently all thirty major league teams operate minor league facilities and summer league teams in the Dominican Republic, and twenty-eight teams have facilities in Venezuela. ${ }^{94}$ Walter LaFeber, one of the most distinguished historians of American foreign policy, brought his well-established concerns about the expansion of American power to bear upon the transnational corporation, Nike, in a recent book. According to LaFeber, Nike is a prime example of how, in harnessing the communications and marketing technologies of the postindustrial age, transnational corporations (with virtually no governmental interference) transmit American-styled sports culture (via sports celebrities and sporting goods) so as to dominate the world in novel ways. ${ }^{95}$ Having not engaged with the wider literature and theoretical debates on empire, cultural imperialism, and globalization, American sport historians have remained on the sidelines with regard to this issue.

While Americans celebrate the diffusion of the nation's dominant pastime, baseball, to all parts of the globe ${ }^{96}$ as evidence of the nation's sporting influence outside 
North America, little attention has been directed to the ways in which the game was adapted and transformed abroad. Nowhere did the colonials better demonstrate their facility with the American "national pastime" than in the Dominican Republic — a country that has produced more professional baseball players than any other, apart from the United States. It has represented the epicenter of Caribbean baseball since the mid-1950s, when Major League Baseball systematically engaged in deceptive practices to secure athletic talent (and were aided and abetted by the Dominican government). During the past several decades, MLB teams have co-opted locals in the recruitment and development process, which John Krich characterizes as a "pimpocracy." ${ }^{\prime}$ In this case, MLB has acted as a typical multinational corporation in its pursuit of valued-added resources, labor power, and ultimately profits. In his 1991 book, Sugarball, ${ }^{98}$ Alan Klein shows how Major League Baseball clubs have operated in a fashion similar to that of other powerful economic and political interests in promoting the presence of the United States throughout the Caribbean (by, for example, conveniently establishing baseball clubs near sugar refineries).

Whereas most of the historical literature on the export of baseball has posited a top-down approach, Klein's work (which incorporates political economy, sociology, and ethnography, as well as history) demonstrates the nuances between hegemony and resistance to imperialism by fans, the local media, and the players themselves in an effort of the Dominicans to retain their hold on the game (despite the deleterious effects that the major leagues have had on the integrity and health of Dominican ball). As Klein writes, "it is one thing to say that hegemonic influences are at work, and quite another to say that they are overriding. Nations that depend on the industrialized West are entirely capable of stemming foreign cultural domination" - a process Klein calls "cultural resistance." 99 As he writes, the "Dominican attitudes toward Americans, the curious mix of approach and avoidance, reflects the tension between hegemony and resistance" as Dominicans both ape North Americans and simultaneously express national pride by "infus[ing] the game with their own raucous, melodramatic, highly individualistic" style of play; "an easygoing attitude" on and off the field; and "music and dancing, and crowds by turns temperamental and tranquil."100

There have been other promising lines of research to suggest that globalization has neither marginalized nationalism nor made contemporary imperialism irrelevant. In his book Baseball on the Border, sociologist Alan Klein uses a focused case study of the border culture between Texas and Mexico not only to challenge an "overly generalized sense of nationalism and sport in the field of sport studies," but also to explore the "establishment and site of national guardedness between nation-states." 101 Focusing on the cities of Laredo, in Texas, and Nuevo Laredo, in Mexico, he argues that the geographical line demarcating two nations is made porous between Mexicans and Mexican Americans by "powerful ethnic, linguistic, and cultural bonds" and "behaviours and attitudes that are now part of the border," which "have become part of a common set of institutions." 102

As Bairner has speculated, if there is something like the Americanization of global sport at work "and if it has been successful, then one might expect to find the clearest evidence in the United States' English-speaking neighbor, Canada." In spite of the mobility of peoples, ideas, and capital inherent in globalizing processes, the research on boundaries and borderlands reveals how nations are constantly (re)imagined communities and, as a result, sometimes complicate notions of cultural imperialism. ${ }^{103}$ Colin Howell has recently explored the ways in which sporting life 
in hinterland or borderland regions of Atlantic Canada replicate the experience of sport in the urban, eastern United States as some have imagined, or whether such places on the margins provide more ambiguous readings than previously assumed by sport historians. ${ }^{104}$ Howell found that, within the borderland region spanning the northeastern border between Canada and the United States during the 1920s through 1940s, except for hockey, "which had its origins in the eastern provinces and spread westward across the country in the last quarter of the nineteenth century," the sporting relationship between the Maritimes and the rest of Canada was one of sporadic contact and limited interaction. He discovered that there was virtually no contact between Maritime baseball and that in central Canada, and that few Maritimers were involved in the dominant sporting organizations central to Canadian nation building. ${ }^{105}$ As he demonstrates, during this particular historical moment, Maritimers created a discourse and "an increasingly professionalised sporting culture that [they] associated with a rapidly urbanizing and sophisticated New England [rather than Canadian] lifestyle." 106 Thus, attention to Maritime Canadian sport provides insight into American cultural imperialism. Nevertheless, as both Klein and Howell maintain, such examples of sporting diffusion cannot be explained simply in terms of a top-down (center-periphery) model of unproblematic imperialism; rather, one must consider the agency and creativity of peoples on the margins (both within and between nations). As Howell writes, the "relationship between metropolis and hinterland is a dialectical one, continually negotiated and re-negotiated, imagined and re-imagined. And nowhere is this fluidity more evident than in the production of culture in transnational borderland communities." 107 This is yet another example of the limits of a nation-centered approach to sport history as well as the need for sport historians to engage with wider scholarly discourses such as political economy and comparative history. ${ }^{108}$

\section{Toward a Research Agenda}

In sum, even though American historians have not explicitly contextualized their narratives within an imperial framework, there has been some marvelously suggestive lines of research to date that might be brought into clearer focus in the construction of a new synthesis of American sport history. Such a line of research is an example of problem-oriented historical inquiry. ${ }^{109}$ In his analysis of histoire probleme in American historical scholarship, Michael Kammen maintains that the distinguishing character of the most innovative recent work has been the "greater degree of self-awareness about what it means to pose historical problems accompanied by a greater degree of precision and clear focus in doing so." 110

Considering sport within the development of American imperial identity constitutes such a problem-oriented line of enquiry and enables one to address a plethora of fruitful historical problems and questions: In what ways did the American use of sport enhance its global standing? How did people in developing nations and those in other European-based empires respond to such efforts? Did other cultures accept, reject, or adapt American sporting practices and the attendant value systems and what might be concluded about the results? ${ }^{111}$ Can we discern differences in attitudes, strategies, approaches, and success in spreading Americanism through sport in these various periods? Does an examination of American sport forms and 
their accompanying institutions, as they gained wider acceptance overseas, bring into bolder relief previously overlooked nuances in U.S. engagement with the world at the dawn of the American Century? ${ }^{112}$ What happens when we put sport and American empire at the center rather than at the periphery of our gaze? To what extent can or should we disconnect American sport history from narratives of nation building or metropolitan dominance? ${ }^{113}$ To date, there have been a couple of sport historians who have offered critiques of American sporting exceptionalism. ${ }^{114}$ How does this framework hold up when placed into a more critical, comparative analysis of both American and British imperial thinking? ${ }^{115}$ How do visions of an American sporting empire differ from those of other imperial traditions, such as Britain?"116 How might our understanding of "race" be broadened when we consider how American racism at home (a type of internal colonialism) bolstered approaches to colonial people abroad? How do such questions challenge the dominant narrative tropes within American sport history? What are the implications for future directions within sport history as well as within the broader, established areas of research within American history?

Such questions resonate more powerfully within mainstream historiography than within the field of sport history, and are, as such, representative of the types of questions that might be addressed in future research in our field of study. ${ }^{117}$ They serve as a clarion call for American sport historians to engage more actively with debates within the "parent" discipline and to better situate their research within the global history of sport. ${ }^{118}$ If historians follow along this path, I suspect that the history of American sport will not appear to be so "exceptional" after all.

\section{Notes}

1. A. Stephanson, "A Most Interesting Empire," in L.G. Lloyd and M.B. Young, eds., The New American Empire: A 21st Century Teach-in on U.S. Foreign Policy (New York: The New Press, 2005), 253. For a useful overview of early American imperial thinking, see Stephanson's Manifest Destiny: American Expansion and the Empire of Right (New York: Hill \& Wang, 1995).

2. Ibid. Stephanson notes how, for example, the centenary of the Spanish-American War in 1998 evoked only a minor bleep within the nation's cultural awareness.

3. With an annual military budget of over a half-trillion U.S. dollars; 700 military bases worldwide; a division of the earth into five military commands; an ambition to dominate space; and its militarized, dominant political parties; to deny the reality of American empire and imperialism is no longer plausible. See Jonathan Schell, "Imperialism without Empire," The Nation, September 13, 2004, 16.

4. R. Steel, "Totem and Taboo," The Nation, September 20, 2004, 29. The books that Steel considered in his review constitute an indicative reading list on the topic: N. Ferguson, Colossus: The Rise and Fall of the American Empire (New York: Penguin, 2005); N. Smith, American Empire: Roosevelt's Geographer and the Prelude to Globalization (Berkeley: University of California Press, 2004); D. Harvey, The New Imperialism (New York: Oxford University Press, 2005); M. Mann, Incoherent Empire (London: Verso, 2003); N. Chomsky, Hegemony or Survival: America's Quest for Global Dominance (New York: Metropolitan, 2004); C. Johnson, The Sorrows of Empire: Militarism, Secrecy and the End of the Republic (New York: Metropolitan, 2004); Z. Brzezinski, The Choice: Global Domination or Global Leadership (New York: Basic, 2004); B. Barber, Fear's Empire: War, Terror and Democracy (New York: Norton, 2004); C. Prestowitz, Rogue Nation: American Unilateralism and the Failure of Good Intentions (New York: Basic, 2004). 
5. As V. DeGrazia begins her excellent bibliographic essay in Irresistible Empire: America's Advance through Twentieth Century Europe (Cambridge, MA: Harvard University Press, 2005), until very recently the relationship of the United States to Europe was "not described in terms of 'imperialism' or 'empire' in any conventional way. Rather, the relationship was characterized as 'empire by invitation,' or 'empire by consensus,' as the effect of 'Americanization,' or, at the cusp of the twenty-first century, in very general terms as an effect of the 'American Century."'

6. Schell, "Imperialism without Empire."

7. J.A. Mangan has been the most influential historian, with numerous authored and edited books and scores of scholarly articles, including Athleticism in the Victorian Edwardian Public School: The Emergence and Consolidation of an Educational Ideology (London, 1981); The Cultural Bond: Sport, Empire, and Society (London, 1992); Pleasure, Profit, Proselytism: British Culture and Sport at Home and Abroad, 1700-1914 (London, 1988); and The Games Ethic and Imperialism: Aspects of the Diffusion of an Ideal (London, 1998). See also R. Holt, Sport and the British (Oxford, 1989). For a more extended list of other key works in British sport history, see M. Johnes's excellent annotated bibliography at http://www.hlst.heacademy.ac.uk/Resources/ sports_history.html.

8. Riess, Major Problems in American Sport History (Boston: Houghton-Mifflin, 1997), viii. Notable exceptions to this scholarly inattention to the use of sport as a tool of diplomacy include B.J. Keys, “The Internationalization of Sport, 1890-1939," in F. Ninkovich, ed., The Cultural Turn: Essays in the History of U.S. Foreign Relations (2001), 201-19; Keys, "Spreading Peace, Democracy, and Coca-Cola: Sport and American Cultural Expression in the 1930s," Diplomatic History 28 (2004), 165-96; and S. Guthrie-Skimizu, "For Love of the Game: Baseball in Early U.S.-Japanese Encounters and the Rise of a Transnational Sporting Fraternity," Diplomatic History 28 (2004), 637-62. The international dimensions of sport history have been examined primarily by sport sociologists and a small handful of historians. See P. Arrnuad and J. Riordan, Sport and International Politics: The Impact of Fascism and Communism on Sport (London: Routledge, 1998); J. Maguire, Global Sport: Identities, Societies, Civilizations (London: Polity, 1999); P. Beck, Scoring for Britain: International Football and International Politics (London: Frank Cass, 1999); and M. van Bottenburg, Global Games (Urbana: University of Illinois Press, 2001).

9. During the past two years, three new books have been published that are chock-full of imaginative insights for the study of sport and American empire: G.R. Gems, The Athletic Crusade: Sport and American Cultural Imperialism (Lincoln: University of Nebraska Press, 2006); B.J. Keys, Globalizing Sport: National Rivalry and International Community in the 1930s (Cambridge, MA: Harvard University Press, 2006); and T.W. Zeiler, Ambassadors in Pinstripes: The Spalding World Baseball Tour and the Birth of the American Empire (Lanham, MD: Rowan \& Littlefield, 2006). For an introduction to Gems's larger book project, see his "Sport, Colonialism, and United States Imperialism," Journal of Sport History 33 (2006), 3-25. Another valuable contribution to this emergent literature is M. Dyreson's "Globalizing the Nation-Making Process: Modern Sport in World History," International Journal of the History of Sport 20 (2003), 91-106.

10. To be sure, there were several articles and book chapters on the diffusion of American sport in the Far East and Latin America through the U.S. military and YMCA, but these efforts scarcely contextualized sport within the longer tradition of American imperialism.

11. Steel, 29.

12. Ernest May, Imperial Democracy (New York, 1961), p. 270. Within the academy, the bestselling work on American foreign policy up through the early 1990s, was S. Ambrose's The Rise to Globalism: American Foreign Policy since 1938 (New York: Penguin, 1974). As Mike Marqusee has recently characterized the phenomenon with regard to a recent Major League Baseball World Series, this cultural insularity “illustrates one of American nationalism's distinctive characteristics: the identification of the universal with the American, an identification rooted in the belief that America is not one nation state among many but the unique embodiment of an idea." 
13. T. McCrisken, "Exceptionalism," in A. DeConde, et al., Encyclopedia of American Foreign Policy, v. 1, 63.

14. For a more expanded discussion of this, see I. Tyrrell, "American Exceptionalism in an Age of International History," American Historical Review 96 (1991), 1031-55; Dorothy Ross, "Historical Consciousness in Nineteenth-Century America," American Historical Review 89 (1984), 909-28; and John Agnew, The United States in the World Economy: A Regional Geography (New York, 1987), 8-15.

15. There have been a surprisingly small handful of sport-oriented articles published in the leading American history journals in recent years. For some notable exceptions to this trend, see B. Keys, "Spreading Peace, Democracy, and Coca Cola"; M. Dyreson, "Icons of Liberty or Objects of Desire? American Women Olympians and the Politics of Consumption," Journal of Contemporary History 38 (2003), 435-60; L. Sklaroff, "Constructing G.I. Joe Louis: Cultural Solutions to the 'Negro Problem' during World War II,' Journal of American History 89 (2002), 958-83; R. Hall, "Before NASCAR: The Corporate and Civic Promotion of Automobile Racing in the American South," Journal of Southern History 68 (2002), 629-68; D. Nathan, "Of Grades and Glory: Rethinking Intercollegiate Athletics," American Quarterly 54 (2002), 139-47; D. Nathan, "Bearing Witness to Blackball: Buck O'Neil, the Negro Leagues and the Politics of the Past," Journal of American Studies 35 (2001), 453-69; P. Grundy, "From Amazons to Glamazons: The Rise and Fall of North Carolina Women's Basketball, 1920-1960," Journal of American History 87 (2000), 112-46; S. Hardy, "Sport in Urbanizing America: A Historical Review," Journal of Urban History 23 (1997), 675-708.

16. In short, American sport historians appear to be content at publishing research-much of it superb-for the consumption of fellow sport studies scholars rather than within the channels read by nonspecialists. There have been only eight panels featuring sport history research at the Organization of American Historians conference since 1996: "Athletics and Assimilation" (1996); "The Curt Flood Case" (2000); "Past Tme: Baseball as History" and "More Than Just a Game: Sports in the Twentieth Century" (2001); "The Politics of Sport and Dance: Black Civil Rights, Power and Integration in Popular Culture" (2003); "Sport, Art and Jazz in Cold War Diplomacy" (2004); and "Sport as a Reflection of American Values" (2007).

17. In 1987, Roberta Park lamented that sports history was "on a descending spiral.... Unless the preparation of more historians within physical education is brought to the level it has finally achieved in a few of our best institutions," she predicted, "it will languish and die as a part of our field." R. Park, "Sport history in the 1990s: Prospects and problems," American Academy of Physical Education Papers 20 (1987), 105.

18. Only Australian historians Murray Phillips and Doug Booth (who maintains that sport historians have been "notoriously coy about their methods and approaches") have scrutinized the neglect of debate on theory and method. Establishing the terrain for a provocative 1999 conference on the "end of sports history (?)," Booth recognized how "the antiquarian, trivial pursuit approach to the sporting past" merely perpetuates the long-antiquated Rankean notion that the "facts" speak for themselves, which he believes still dominates the field of sports history. Although, as Booth argued, "the empiricism and rich detail of the better monographs have provided knowledge essential to understanding the rise and character of modern sport, and although the better practitioners cannot be accused of aimlessly wander[ing] in the dark forest of the past gathering facts like nuts and berries, the sub-discipline continues to face charges of irrelevance." Booth stated that sport historians ought to pay more attention to the intellectual (and institutional) interrelationships of sport with physical education; engage the science and forge new relationships with the scientific subdisciplines that constitute physical education; and make their scholarship more relevant to students - who in many cases, perceive that "sports history amounts to the regurgitation of lists of winners and apparently significant events." See D. Booth, "Sports History: What Can Be Done?" Sport, Education and Society 2 (1997), 191, 197 
19. Hardy, "Where Did You Go, Jackie Robinson? Or, the End of History and the Age of Sport Infrastructure" Sporting Traditions 16 (1999), 93, 98. This was a keynote presentation at the 1999 Australian Society for Sport History conference, organized by Doug Booth, on the theme "The End of Sport History?"

20. In truth, imperial historians as well as historians of American diplomacy and foreign policy have been even more insular in their consideration of "cultural" forms, such as sport. Barbara Keys has recently written that whereas "sport has elicited more passionate interest from greater numbers of people than other aspects of culture, historians of international relations have devoted little attention to it." Other than Barbara Keys, the only other recognized diplomatic historian who comes to mind is Walter LaFeber, whose book Michael Jordan and the New Global Capitalism (New York: Norton, 1999) provides a model for this kind of cross-fertilizing scholarship. The Harvard professor of history Charles Maier has recently written how empires emphasize dramaturgy: "All societies may celebrate prowess, but from the Colosseum to the Super Bowl, in the West at least, empires particularly rely on the sports of the amphitheatre that reward star players with fame and fortune. They nurture a culture of spectatorship to create rituals of shared experience." See C. Maier, "An American Empire? The Problems of Frontiers and Peace in TwentyFirst Century Politics," in L. Gardner, and M.B. Young, eds., The New American Empire: A 21st Century Teach-in on U.S. Foreign Policy (New York: New Press, 2005), xv.

21. T. Bender, "Historians, the Nation, and the Plenitude of Narratives," in Bender, ed., Rethinking American History in a Global Age (Berkeley: University of California Press, 2002), 3.

22. J. Higham, "The Future of American History," Journal of American History (1994), 1290-1, 1301. Higham is merely one of many historians who have advocated a move of the collective gaze away from the nation state as its primary focus of inquiry. See for instance D. Thelen, "The Nation and Beyond: Transnational Perspectives on United States History," Journal of American History 86 (1999), 965-75; I. Tyrrell, "American Exceptionalism," 1031-60; and E. Foner, "American Freedom in a Global Age," American Historical Review 106 (2001), 1-16.

23. For a superb cross-section of the cutting-edge work within American history, see "The Nation and Beyond" a special issue of The Journal of American History 86 (December 1999). Moreover, the Organization of American Historians has organized conference themes such as "America and the Wider World" and "Internationalizing American History" in recent years.

24. Bender, Rethinking American History, 5-6.

25. Ibid., 3; Tyrrell, "American Exceptionalism." See also D. Thelen, "The Nation and Beyond: Transnational Perspectives on United States History," Journal of American History 86 (1999), 965-78.

26. Tyrrell, "American Exceptionalism," 1055. According to Tyrrell, American historians interested in developing a transnational approach must "specify the relations of three phenomena: first, the international context of national action in all of its manifestations. This would include not only international economic relations but also transnational connections in religion, culture and social life; second, the development of the nation-state constrained by these international contexts; third, the groups and classes that operate both within the nation-state and at the international level" (p. 1053).

27. M.A. Heiss, "The Evolution of the Imperial Idea and U.S. National Identity," Diplomatic History 26 (Fall 2002), 511-12.

28. Guttmann attempts to do this in his recent book Sport: The First Five Millennia (Amherst: University of Massachusetts Press, 2004). There has been a notable trend in comparative history in the United States that has allowed some systematic testing of exceptionalist ideas. For more on this, see J. Higham, "Changing Paradigms: The Collapse of Consensus History," Journal of American History 76 (1989), 465. There remains, however, a need for American sport historians to develop more explicit comparisons between the United States and Britain in particular (as well as Europe more generally). This research agenda will be advanced through the forthcoming publication of 
The Routledge Companion to Sports History, S. Pope and J. Nauright, eds. (London: Routledge, 2009) - the first major work charting the global development of sport historiography.

29. I would like to thank the editor, Don Morrow, and an external reviewer for effectively raising this point in their analysis of an earlier version of this article.

30. One could point to various sporting developments, such as the international promotion of baseball and basketball as an indicator of exceptionalist rather than imperial mentality, or more recently, the international marketing of professional (NFL) football. From a cross-cultural, comparative perspective, one could also note how the diffusion of English football in South America has represented only an informal empire given that Argentineans and Brazilians were all too eager to take the game and turn it into their own, or how the global success of the English Premier league cannot be restricted to British cultural imperialism but, rather, a burgeoning market for global sports entertainment.

31. For an expanded treatment of this practice, see D.H. Fisher, Historians' Fallacies: Toward a Logic of Historical Thought (New York: Harper, 1970).

32. Ibid., 277-81. Fisher lists some fifteen types of definitions and assesses the problematical issues for historians in choosing a suitable one.

33. Ibid., 276.

34. For a useful, brief primer on postmodernism, see C. Butler, Postmodernism: A Very Short Introduction (Oxford: Oxford University Press, 2002). For an invaluable collection of key works on postmodernism and history, see K. Jenkins, ed., The Nature of History Reader (London: Routledge, 2004). M. Phillips's edited (NASSH award winning) collection Deconstructing Sport History is the pioneering book-length treatment of this neglected and poorly understood theoretical tradition within the field of sport history. For more on epistemology within sport history, see D. Booth, The Field.

\section{Butler, Postmodernism, 35.}

36. The field of American sport history has exuded few signs of internal debate in recent years. I am unaware of any substantive discussion on calls for a new paradigm (as I suggested ten years ago in the introduction to my edited collection, The New American Sport History). The closest evidence of a debate upon method and epistemology that I've seen in recent years within American sport history is A. Ritchie's response to N. Struna's "Reframing the Direction of Change in Sport History," International Journal of the History of Sport 18 (2001) _ "Seeing the Past as the Present It Once Was," International Journal of the History of Sport 20 (2003), 128-50, wherein Ritchie takes Struna to task for not being sufficiently "empirical" in her (mis)use of bicycling examples in arguing for an essentially chronological, empirical rendering of the American sporting past. The ensuing debate between two well-respected sport historians, however, provides a view of where sport history has been (locked into) the past but certainly not where the cutting edge currently is with respect to the postmodernist challenge regarding "facts," empiricism, chronology, and the like.

37. Ferguson, Colossus, 2.

38. W.A. Williams, The Contours of American History, 1961, 215; see also, for example, W. LaFeber, "The Evolution of the Monroe Doctrine from Monroe to Reagan," in L. Gardner, ed., Redefining the Past: Essays in Diplomatic History in Honor of William Appleman Williams (Corvallis, OR, 1986).

39. Heiss, "Evolution of the Imperial Idea," 520-4.

40. E.J. Gorn and W. Goldstein, A Brief History of American Sports, 2d ed. (Urbana: University of Illinois Press, 2004), p. 5. For the most succinct overview of early American sport, see Gorn, "Sports through the Nineteenth Century," in The New American Sport History: Recent Approaches and Perspectives, ed. S.W. Pope (Urbana: University of Illinois Press, 1997), 33-57. A classic analysis of native Indian games and accompanying rituals can be found in George Mooney, 
"Cherokee Ball Play," American Anthropologist (1890); see also S. Culin, Games of the North American Indians (Washington, DC, 1907).

41. See most notably J. Bloom, To Show What an Indian Can Do: Sports at Native American Boarding Schools (Minneapolis: University of Minnesota Press, 2000); and C.R. King, ed., Native Athletes in Sport \& Society: A Reader (Lincoln: University of Nebraska Press, 2005). Jim Thorpe was a product of the Carlisle school, who, as a two-time All American football player, led Carlisle to an 11-1 record in 1911 (including a victory over Harvard); thereafter he won gold medals in the pentathlon and decathlon at the 1912 Olympics. During the following year it was discovered that, prior to winning gold in Stockholm, he had played professional baseball and was stripped of his medals by the American Olympic Committee. He later played both professional baseball and football during the 1910s-20s and in 1950, Thorpe was named the outstanding athlete of the first half of the twentieth century - and continues to be ranked in the top ten of America's greatest athletes.

42. R. Gamache, "Assimilation's Last Stand: Representations of American Indian Athletes in the Carlisle School Media," paper presented at the American Journalism History Association conference, New York University, March 24, 2007 (copy in author's possession).

43. The classic work on this is E. Morgan's American Freedom, American Slavery (New York: Norton, 1976). For a more recent synthesis of the differing conceptions of freedom that have been articulated throughout American history, see E. Foner, The Story of American Freedom (New York: Norton, 1999).

44. D.K. Wiggins, "Sport and Popular Pastimes: Shadow of the Slavequarter," Canadian Journal of the History of Sport, 11 (May 1980): 61-88. A revised version of this early piece was published as "Sport and Popular Pastimes: Shadow of the Slave-quarters," in Wiggins, ed., Sport in America. See also Wiggins, "From Plantation to Playing Fields: Historical Writing of the Black Athlete in American Sport," Research Quarterly for Exercise and Sport 57 (1986). For a comprehensive review of the earlier scholarship on African Americans, see J.T. Sammons, "'Race' and Sport: A Critical, Historical Examination," Journal of Sport History 21 (1994), 203-78. For a more recent engagement with race and American sport, see S.W. Pope, "De-centering 'Race' and (Re)presenting 'Black' Performance in Sport History," in Deconstructing Sport History: The Postmodern Challenge, M. Phillips, ed. (Albany: State University of New York Press, 2005), 147177. See also D. Wiggins and P. Miller, eds., The Unlevel Playing Field: A Documentary History of the African American Experience in Sport (Urbana: University of Illinois Press, 2004).

45. See W.H. Boulware's "Black Urban Leisure Pursuits and Cultural Identity in Eighteenth Century South Carolina and Georgia," International Journal of Regional and Local Studies, Series 2, 1 (2005), 83-106; and his doctoral thesis, "The Evolution of Sport and Recreation in Early South Carolina and Georgia," University of Cambridge, 2007.

46. Gems, "Sport, Colonialism, and United States Imperialism," a paper delivered to the Chicago Seminar on Sport History, copy in author's possession, p. 3. By 1890 foreigners owned $75 \%$ of the acreage, much of it in plantations, where baseball served as a social control mechanism for a multicultural labor force. For additional documentation of this, see Gems, Athletic Crusade, 66-81.

47. W.J. Baker, Playing with God: Religion and Modern Sport (Cambridge, MA: Harvard University Press, 2007), 44.

48. K. Cohen, “'To Give Good Sport”: The Making and Meaning of Sporting Leisure in Early America, 1750-1840," PhD diss., University of Delaware, 2007, 1-12.

49. Cohen, "Projecting Sport History: Affecting Instead of Reflecting Mainstream Historiography," paper presented at the North American Society for Sport History conference, Glenwood, Colorado, May 2006.

50. I've gleaned these insights through personal correspondence with Cohen. His dissertation takes the argument a step further and asserts that the competitive, unpredictable sporting milieu was 
not only symptomatic of an emergent capitalist economy, but it also, perhaps more significantly, encouraged a capitalist culture by embracing risk.

51. See D. Mrozek, Sport and American Mentality, 1880-1910 (Knoxville: University of Tennessee Press, 1982); M. Dyreson, Making the American Team: Sport, Culture and the Olympic Experience (Urbana: University of Illinois Press, 1998); and S.W. Pope, Patriotic Games: Sporting Traditions in the American Imagination, 1876-1926 (NY: Oxford University Press, 1997)—a second edition of this book (with a new introductory essay) was published by the University of Tennessee Press in 2007.

52. T. Zeiler, Ambassadors in Pinstripes: The Spalding World Baseball Tour and the Birth of the American Empire (Lanham, MD: Rowan\& Littlefield, 2006), ix-x.

53. Ibid., 187, 41, 191.

54. Heiss, "Evolution of the Imperial Idea," 531-2.

55. Bender, Nation among Nations, 191. My thinking of this development has been most influenced by M. Parenti. See, for example, his The Sword and the Dollar: Imperialism, Revolution and the Arms Race (New York: St. Martin's 1988). As Bender writes, the strategies developed by the United States in places such as Cuba in the early twentieth century, which established financial hegemony, continues to this day in the form of the International Monetary Fund and the World Bank-vehicles of American interest and fiscal expertise - and these are even more powerful instruments of empire. As Bender characterises the case, "debt produces dependency and loss of control for the debtor, but the result advances American empire almost imperceptibly, masking power as a technique. In the twentieth century, then, American power found a barely visible means to influence, even control, global financial management. It sustained a world responsive to American economic aspirations and moral expectations" (p. 241).

56. G. Gerstle, American Crucible: Race and Nation in the Twentieth Century (Princeton: Princeton University Press, 2001), 4-5, 8-9. Gerstle argues that the [Theodore] "Rooseveltian" nation fell apart during the 1960s-triggered by the movement for equality, the black nationalist renunciation of America, and the war in Vietnam. Gerstle maintains that by 1970, "neither the civic nor racial traditions of American nationalism retained enough integrity to serve as rallying points for those who wished to put the nation back together" (p. 10).

57. See M. Dyreson, "Sport and Visions of the 'American Century,"” Peace Review 11 (December 1999), 565-72.

58. The literature on the development of an American sporting culture is voluminous. See for example Pope, Patriotic Games; Dyreson, Making the American Team; Mrozek, Sport and American Mentality, 1880-1910.

59. Bender, Nation among Nations, 192.

60. Gems, "Sport, Colonialism, and United States Imperialism," paper delivered at the Chicago Seminar on Sport, 32-3 (copy in author's possession). See also Gems, "Puerto Rico: Sport and the Restoration of National Pride," International Journal of Regional and Local Studies, Series 2, 1:1 (2005), 107-20; and "Sports, War and Ideological Imperialism," Peace Review 11 (December 1999), 573-8.

61. Ibid., 7, 16.

62. See Zeiler, 88 and passim. Interestingly, as Zeiler recognizes, "baseball took hold in places that the tour had not reached, such as Japan and the Caribbean, and it was ironic that these were nations of color rather than the white imperial outposts so lauded by the tourists" (p. 188).

63. As Gems has written in his recent book, there has been, until recently, a conspicuous absence of the colonial voice within American scholarship. "Only recently have Asian American and Latino scholars offered a critical perspective of colonial revisionism, yet none have examined sport. American sport historians, in particular, have greatly neglected imperial studies." See Gems, The Athletic Crusade, 16. 
64. The most authoritative collection of recent work on race in American sport scholarship is P. Miller and D. Wiggins, eds., Sport and the Color Line: Black Athletes and Race Relations in the Twentieth Century (London: Routledge, 2004). For a useful, although now dated, review of the literature, see J. Sammons, "Race: A Critical, Historical Examination," Journal of Sport History 21 (1994), 203-78. Sport historians have been, on the whole, rather uncritical and reductionistic in using an essentialized notion of "race" when referring to black athletes, thereby obscuring the racialized nature of "whiteness." Despite the formidable body of scholarship on race, sport historians have paid insufficient attention to how race as a system operates. I've weighed in on this issue by arguing that we can theorize embodied practices (such as sport) without resorting to either the essentializing concept of "race" or a predominant focus on "blackness." See Pope, "Decentering Race and (Re)presenting 'Black' Performance in Sport History: Basketball and Jazz in American Culture, 1920-1950," in M. Phillips, ed., Deconstructing Sport: The Postmodern Challenge (Albany: State University of New York Press, 2005), 147-80.

65. Gems, The Athletic Crusade, 2.

66. F. Cogliano, "Baseball and American Exceptionalism," in A. Smith and D. Porter, eds., Sport and National Identity in the Postwar World (London: Routledge, 2004), 144-67; Kammen, "Historians, the Nation, and the Plenitude of Narratives," passim, in T. Bender, Rethinking American History.

67. W.J. Baker, Playing with God: Religion and Modern Sport (Cambridge, MA: Harvard University Press, 2007), 254.

68. See Pope, Patriotic Games, 150-1.

69. The effort was led by YMCA's Elwood Brown, who had pioneered the Far Eastern Games several years earlier to promote better relations among the Chinese, Japanese, and Filipino.

70. Pope, Patriotic Games, 152-3.

71. M. Dyreson, "Globalizing the Nation-Making Process: Modern Sport in World History," International Journal of the History of Sport 20 (2003), 97. Dyreson devotes more attention to this in his book Making the American Team. See also his forthcoming edited book, Crafting Patriotism for Global Dominance: America at the Olympics (London: Routledge, 2007).

72. Dyreson, "Globalizing the Nation-Making Process," 102.

73. Keys, Globalizing Sport, 5.

74. Ibid., 7. Keys notes that although "sport has elicited more passionate interest from greater numbers of people than other aspects of culture, historians of international relations have devoted little attention to it" (p. 10). As exceptions to this neglect, see P. Beck, Scoring for Britain: International Football and International Politics, 1900-1939 (London: Frank Cass, 1999), and P. Arnaud and J. Riordan, eds., Sport and International Politics: The Impact of Fascism and Communism on Sport (London: Routledge, 1998).

75. Keys, Globalizing Sport, 15. See also her excellent chapter- "Democracy and International Sport: The United States," 64-89.

76. I'm incorporating the neat schematic rendering offered by M. Heiss in this essay. See "Heiss, Evolution of the Imperial Idea," 533-38. The scholarly literature on post-WWII American foreign policy and empire is simply too vast to engage in his piece. For a brief overview of American sport during WWII, see W. Wakefield, Playing to Win: Sports and the American Military, 1898-1945. Albany: State University of New York Press, 1997; Pope, "Sports: World War II', in J.S. Resch, ed., Americans at War: Society, Culture, and the Homefront, Macmillan, 2005, v. 3; and K. Jay, More than Just a Game: Sport in American Life since 1945 (New York: Columbia University Press, 2004), 9-30.

77. For a useful analysis of Luce's worldview, see D.W. White, "The 'American Century' in World History," Journal of World History 3 (1992), 105-27. Whether or not the American relationship with Europe has been "imperialist" or not has been debated by both American and European historians. See for example, G. Lundestaad, The United States and Western Europe since 1945: 
From "Empire" by Invitation to Transatlantic Drift (Oxford: Oxford University Press, 2003); O. Zunz, Why the American Century? (Chicago: University of Chicago Press, 1998); P. Kennedy, The Rise and Fall of the Great Powers (New York: Random House, 1987); G. Arrighi, The Long Twentieth Century: Money, Power, and the Origins of Our Times (New York: Verso, 1994); R. Kroes, IfYou've Seen One, You've Seen the Mall: Europeans and American Mass Culture (Urbana: University of Illinois Press, 1996); R. Pells, Not Like Us: How Europeans Have Loved, Hated, and Transformed American Culture since World War II (New York: Basic Books, 1997); and R. Kagan, Of Paradise and Power: America vs. Europe in the New World Order (New York: Knopf, 2003).

78. H.R. Luce, "The American Century," Life 17 February 1941, 61-5.

79. White, “'American Century' in World History," 118. As White writes, the reaction abroad to the idea of the American Century was "at best grudging. To U.S. allies it may have symbolized America's position of power, but it did not seem sensitive to their interests. . . When this power was imposed not by attraction of modern or democratic institutions but through force, that dominance provoked resistance."

80. Heiss, "Evolution of the Imperial Idea," 533.

81. The limited scope of this essay does not allow for an elaboration on this evocative point. Young writes that the language of imperialism, "of the act of creating and sustaining empire, is immediate, direct, often monosyllabic, given to slang not to euphemism. Its dominant tense is the imperative. The language of empire is benign, nurturing, polysyllabic; its preferred tense is the future conditional. The language of empire reassures." Given this typology, the language Americans employed with regard to sport in the late nineteenth and early twentieth centuries was that of empire, whereas the language used in more recent decades would be that of imperialism. See M.B. Young, "Imperial Language," in L. Gardner and M. Young, eds., The New American Empire, 32-3.

82. See K. Jay, More than Just a Game: Sports in American Life since 1945 (New York: Columbia University Press, 2004), 11.

83. Ibid., 12.

84. Ibid., 52. See also D. Zirin, Welcome to the Terrordome: The Pain, Politics and Promise of Sports (Chicago: Haymarket Books, 2007), 126.

85. Ibid., 63. For a succinct, trenchant assessment of American sporting rivalry with the Soviet Union during the Cold War, see Bairner, Sport, Nationalism, and Globalization (Albany: SUNY Press, 2001), 112-3.

86. Keys's Globalizing Sport provides some rich suggestions of how such a line of research into sports diplomacy in the Cold War era might be pursued. The best existing model for such a work is M. Polley's study of the British context in Moving the Goalposts: A History of Sport and Society since 1945 (London: Routledge, 1998).

87. M. Silk et al., Sport and Corporate Nationalisms (Oxford: Berg, 2005), 2, 4, 7.

88. M. Dyreson, "Globalizing the Nation-Making Process: Modern Sport in World History," International Journal of the History of Sport 20 (2003), 93. M. Silk, D. Andrews, and C.L. Cole consider the ways in which globalization has brought about the "changing," as opposed to the "withering," of the nation.

89. A. Bairner, Sport, Nationalism, and Globalization, 113.

90. The exception to this is Gems, who has scrutinized some of these issues in The Athletic Crusade.

91. M. Falcous and J. Maguire, "Making it Local? National Basketball Association Expansion and English Basketball Subcultures," in Silk, et al., Sport and Corporate Nationalisms, 13-34. The authors document how the NBA television ratings during the mid- to late-1990s were not only well below those of dominant sports, but also below those previous American imports, such as NFL-Europe, which attracted over four times as many viewers during the late 1980s. 
92. Ibid., 30. For another incisive case study of this trend of marketing American sport outside the United States, see M. Giardina and J. Metz, "All American Girls? Corporatizing National Identity and Cultural Citizenship with/in the WUSA," in Silk, et al., 109-20. Maguire has written extensively on the globalization of sport. See his Global Sport: Identities, Societies, Civilizations (London: Polity, 1999); see also T. Miller et al., Globalization and Sport (London: Sage, 2001). D. Andrews and S. Jackson have published some excellent work on the imperial mentality of the NBA. See, for example, the special issue of the Sociology of Sport Journal, edited by D. Andrews, 13 (1996); as well as Andrews, "Whither the NBA, Whither America?" Peace Review 11 (1999), 505-16; S. Jackson and D. Andrews, "Between and Beyond the Global and the Local," International Review of the Sociology of Sport 43 (1999), 31-42.

93. R. Lewis II, “'Soft Ball': MLB Shifts from Neocolonizer to Multinational Corporation," paper presented at the Cooperstown Symposium on Baseball and American Culture, June 2006. The term soft power is attributed to J.S. Nye as delineated in his Bound to Lead: The Changing Nature of American Foreign Policy (New York: Free Press, 1990), and more recently, Soft Power: The Means to Success in American Foreign Policy (New York: Foreign Affairs, 2004).

94. J. Howell cites this from A. Guerva and D. Fidler's Stealing Lives: The Globalization of Baseball and the Tragic Story of Alexis Quiroz, (Bloomington: University of Indiana Press, 2003) in his chapter "From SBC Park to the Tokyo Dome: Baseball and (Inter) Nationalism," in Silk, et al., Sport and Corporate Nationalisms, 242.

95. W. LaFeber, Michael Jordan and the New Global Capitalism (New York: Norton, 1999).

96. This, in spite of the fact that gridiron football has eclipsed baseball as the dominant American sport. Nevertheless, baseball, and even basketball, are far more popular outside the United States than is football.

97. See Lewis, "Soft Ball," 10; J. Krich, El Beisbol: Travels through the Pan-American Pastime (New York: Prentice Hall, 1989), 111. Other key works on baseball in Latin America include Rob Ruck, The Tropic of Baseball: Baseball in the Dominican Republic (Westport: Meckler, 1991); and P. C. Bjarkman, Baseball with a Latin Beat: A History of the Latin American Game (Jefferson, NC: McFarland, 1994).

98. A. Klein, Sugarball: The American Game, The Dominican Dream (New Haven: Yale University Press, 1991), 6.

99. Ibid., 3, 47, 112.

100. Ibid., 152.

101. Klein, Baseball on the Border: A Tale of Two Laredos (Princeton: Princeton University Press, 1997), 257, 252.

102. Ibid., 254-55.

103. C. Howell, "Borderlands, Baselines and Bearhunters: Conceptualizing the Northeast as a Sporting Region in the Interwar Period," Journal of Sport History 29 (2002), 252. For a more extensive treatment of Canadian sport history, see Howell's Blood, Sweat, Cheers: Sport and the Making of Modern Canada (Toronto: University of Toronto Press, 2001). For a recent work that seeks to problematize sporting development within a rigid notion of the nation state, see R. Martin and T. Miller, eds., SportCult (Minneapolis: University of Minnesota Press, 1999).

104. Bairner, Sport, Nationalism, and Globalization, 113, has challenged scholars to explore the impact of the globalization of sport within specific, regional contexts.

105. Howell, Blood, Sweat, Cheers, 266.

106. Ibid., 259.

107. Ibid., 253-54. 
108. Howell is a rare example of an historian who came to sport after having developed an established tradition within another area of historical scholarship. As a leading Canadian social historian and former editor of the Canadian Historical Review, Howell shifted to sport history in mid-career but did so by continuing to engage the debates within the field of Canadian and postcolonial history. I also have a connection to Canadian history. I originally commenced my postgraduate work in Canadian social and labor history at the University of Maine in 1988, and although I did not ultimately write a thesis in this area, I developed a secondary field in Canadian history (and am thus, appreciative of historians such as Howell, who conceptualizes his work within Canadian and world history as well as sport history).

109. M. Kammen, "An Americanist's Reprise: The Pervasive Role of Histoire Probleme in Historical Scholarship Concerning the United States since the 1960s," in L. Masur, ed., The Challenge of American History (Baltimore: Johns Hopkins University Press, 1999), 3.

110. Ibid., 3-4.

111. These questions are explored by Gems in The Athletic Crusade.

112. S. Guthrie-Shimizu explores this question in "For the Love of the Game: Baseball in Early U.S.-Japanese Encounters and the Rise of a Transnational Sporting Fraternity," Diplomatic History 28 (2004), 638 and passim.

113. This question is pursued by Howell in his suggestive essay "Borderlands, Baselines and Bearhunters: Conceptualizing the Northeast as a Sporting Region in the Interwar Period," Journal of Sport History 29 (2002).

114. In 1995, Nathan Abrams declared unequivocably that "the way forward is clear. American sport historiography needs to break out of . . the myth of its sports' exceptionalism." Nathan D. Abrams, "Inhibited but Not Crowded Out': The Strange Fate of Soccer in the United States," International Journal of the History of Sport 12 (1995), 1-17. More recently, Francis Cogliano has demonstrated how, for example, Americans' attachment to baseball if viewed from a hemispheric or transpacific perspective, would not seem to be so unique if one compares the relationship between baseball and American imperialism in the Caribbean, with cricket and British imperialism elsewhere. See Cogliano, "Baseball and American Exceptionalism." According to J.A. Mangan, the United States is only exceptional "at a time of the increasing globalization of sport, it favours increasing "exceptionalism." Herein lies the paradox of American sport: "its self-absorbed insularity, often viewed by outsiders as an indrawn and obdurate isolationism," Mangan argues, is ironically "coupled with an over-weaning and insensitive 'imperialism' ...; [American sport] maintains its internal image of supremacy by exerting its domestic power to deny other the opportunity to challenge it.” J.A. Mangan, “Empire in Denial': An Exceptional Kind of Imperialism," International Journal of the History of Sport 2 (2005), 1194. Mangan's provocative argument was a concluding rejoinder in a special issue on American sport in the IJHS (edited by M. Dyreson).

115. I, too, ventured a similar statement during a talk at the 2006 North American Society for Sport History conference but it was greeted coolly and skeptically. The most influential treatment of this argument is Andrei S. Markovits, “The Other 'American Exceptionalism': Why Is There No Soccer in the United States?" International Journal of the History of Sport 7 (1990), 230-64, and in more developed form in Markovits and S. Hellerman, Offside: Soccer \& American Exceptionalism (Princeton: Princeton University Press, 2001). A more recent take on this theme with some valuable insights is S. Brown, "Exceptionalist America: American Sport Fans' Reaction to Internationalization," International Journal of the History of Sport 22 (November 2005), 1106-35.

116. In his address at the 2004 "Historians on Sport" conference hosted by the International Centre for Sport History and Culture, Professor Stephen Howe delineated a host of conceptual schisms inherent in exploring comparative histories of sport and empire, including the epistemological 
disputes among historians; the general lack of interaction between political economists and cultural historians of empire; the differences between "new" and "old" approaches to imperial history; the competing historical narratives based upon capitalism and colonialism; the impact of empire on metropoles and the general making and remaking of place and space; the appropriate modes of analysis (national vs. transnational); the appropriate analyses of gender, race, and masculinity; anti-colonial resistance; and finally, the larger question — what, precisely, is a scholarly analysis of sport and empire for?

117. I plan to grapple explicitly with these and other questions in a future book-length project.

118. It is unclear to this author, a keen historiographer, what (if any) the central debates are within American sport history. Whereas most scholarly associations thematically conceptualize conferences, the North American Society for Sport History does not order their annual conference in such a fashion; rather, the conference organizers group the proposed papers into recognizable categories so as to impose some thematic coherence. Given the success of the K. Cohen, D. Booth, and C. Howell session at the 2006 conference-which came closest to a "state of the art" discussion of the field that I have seen in NASSH during the past fifteen years-perhaps such a thematic, historiographical session can be included in subsequent conferences.

\section{Acknowledgments}

I would like to thank Susan Bandy, Doug Booth, Gerald Gems, Richard Holt, Don Morrow, and John Nauright for their comments, advice, and support. 